\title{
sustainability
}

ISSN 2071-1050

www.mdpi.com/journal/sustainability

Review

\section{Breeding Food Legumes for Resistance to Storage Insect Pests: Potential and Limitations}

\section{Gemechu Keneni ${ }^{1,2, *}$, Endashaw Bekele ${ }^{2}$, Emana Getu ${ }^{2}$, Muhammad Imtiaz ${ }^{3}$, Tebkew Damte ${ }^{4}$, Bayeh Mulatu ${ }^{1}$ and Kifle Dagne ${ }^{2}$}

1 Holetta Agricultural Research Center, P.O. Box 2003, Addis Ababa, Ethiopia;

E-Mail: bayeh65@yahoo.com

2 Faculty of Life Sciences, Addis Ababa University, P.O. Box 1176, Addis Ababa, Ethiopia; E-Mails: endashawbw@yahoo.com (E.B.); egetudegaga@yahoo.com (E.G.);

kifledagne2011@hotmail.com (K.D.)

3 International Center for Agricultural Research in the Dry Areas (ICARDA), P.O. Box 5466, Aleppo, Syria; E-Mail: m.imtiaz@cgiar.org

4 Debre Zeit Agricultural Research Center, P.O. Box 32, Debre Zeit, Ethiopia;

E-Mail: tebkew@yahoo.com

* Author to whom correspondence should be addressed; E-Mail: gemechukeneni@yahoo.com; Tel.: 251-0911-856440; Fax: 251-011-237-03-77.

Received: 24 May 2011; in revised form: 9 August 2011 / Accepted: 11 August 2011 /

Published: 31 August 2011

\begin{abstract}
Storage insect pests cause significant losses of food legumes particularly in the Tropics and the Sub-tropics. The most important species of storage insect pests of food legumes include Callosobruchus chinensis, C. maculatus, C. analis, Acanthoscelides obtectus, Bruchus incarnatus, B. rufimanus, B. dentipes, B. quinqueguttatus, B. emarginatus, B. ervi, B. lentis and B. pisorum. Effective post-harvest insect pest control measures should constitute part of the overall crop husbandry practices for preserving the quality of produce. Storage insect pests are commonly controlled using chemical insecticides which, however, bear many drawbacks related to high cost, environmental pollution and food safety risks. Breeding legume crops to improve their resistance against storage insect pests, although having technical limitations, is the best way of overcoming these disadvantages in an environment-friendly manner. In this paper, we present the findings of our extensive reviews on the potential of breeding resistant varieties of food
\end{abstract}


legumes against storage insect pests along with the major technical limitations one would likely encounter and the prospective ways of tackling them.

Keywords: resistance breeding; food legumes; storage insect pests

\section{Introduction}

Storage insect pests cause serious losses to all legume crops in both quality and quantity, particularly in the Tropics and Sub-tropics where temperatures and relative humidity are high. Unlike field insect pests, storage insect pests are very much more serious not only because of the magnitude of the losses they cause but also the irreversibility of the damage they inflict on the produce [1]. Food quality is very important in developing countries, where grain legumes are the major source of high protein foods for the majority of the population. Secondary re-infestation of grain legumes by hatched storage pests affects not just farmers but post-harvest traders and ultimately consumers in the paddock to plate value chain $[2,3]$.

The most important species of storage insect pests of food legumes include: Callosobruchus chinensis, C. maculatus, C. analis, Acanthoscelides obtectus and Bruchus incarnatus [4,5]. In addition, B. rufimanus, B. dentipes, B. quinqueguttatus, B. emarginatus, B. ervi, B. lentis and B. pisorum may also cause significant losses in some legumes [4,6]. Losses as high as $50 \%$ may often be encountered in some of the important legumes such as faba bean, field pea, chickpea and lentil from some belligerent storage insect pests like $C$. chinensis $[7,8]$. Even with only a small amount of actual biological losses, economic losses can reach up to $100 \%[9,10]$. The seeds of legumes, once damaged by storage insects, are no longer fit for planting (due to poor germination) or for food or feed (due to spoilage and bad smell) [11,12]. Despite the importance of storing seeds as a strategy of stabilizing market prices associated with the balance between supply and demand [1], the damages often wreaked by the pests, particularly under small-scale farmers' conditions, obstruct optimal use of the market opportunities [7,8]. Traders, food processors, and finally consumers also lose from storage pest damage.

Several options have proved effective in controlling storage insect pests; including environmental manipulations to discourage their growth, development and reproduction. Such environmental manipulations can be attained by employing a number of control measures like the use of chemical insecticides and cultural and physical control methods. Chemical pesticides are effectively used against storage insect pests but are inseparably associated with a number of drawbacks including high costs and concerns about environmental pollution and food safety.

An effective and environment-friendly management option against storage insect pest in different legume crops could be achieved by improving the genetic resistance of the host plant [10,13-17]. Nevertheless, most of the breeding programs pursued hitherto focus more on improving seed yield and quality than improving resistance against storage insect pests. This is despite the importance of the latter beyond the direct losses to the farmer along the product value chain to the consumer, both rural and urban. In this paper, we discuss the potential and technical limitations of breeding legume 
crops for resistance against storage insect pests and some possible ways to overcome the limitations based on extensive reviews of past breeding programs.

\section{Why Breeding Crops for Resistance against Storage Insect Pests?}

The use of resistant varieties against storage insect pests, when successful, has a number of comparative advantages over other control measures, particularly the use of chemical insecticides.

Firstly, controls based on chemical insecticides mostly need to be repeated periodically and hence are more expensive in comparison with genetic manipulation of the crops themselves for resistance to storage insects. Developing countries relying on imports of agrochemicals including insecticides often suffer from shortages of supplies at the farm and village level, and they are also becoming unaffordable [14]. It is likely that prices of agrochemicals in general and chemical insecticides in particular will rather rise in the future as the reserves of non-renewable raw materials are dwindling and the world is currently facing unprecedented economic crises [18]. The storage structures in use under small-scale production conditions of the Tropics and Sub-tropics are not suitable for the use of chemical insecticides especially for formulations like fumigants [15]. In most cases, the storage structures are built within the same houses the families dwell and this makes the use of chemical insecticides more hazardous to human health. Since seed lots used for consumption and planting are kept in the same granaries, the use of chemical insecticides as a means of controlling storage insects is not advisable [15,19]. Furthermore, the prevalence of large stocks of sub-standard and poor quality insecticides in a number of developing countries further aggravates the problem. Conversely, until the recent past, availability and costs of chemical insecticides have not been serious problems in the developed countries. However, since environmental pollution and food safety are issues of great concern, the additional costs incurred to ensure safer pesticides place upward pressure on costs.

Secondly, the physical environment and price ratios between external inputs and farm outputs may not allow the use of large quantities of insecticides in larger parts of the Tropics and Sub-tropics where production of food legumes by and large takes place under marginal conditions [20]. On the other hand, once cultivars resistant to storage insect pests become available, their adoption by the large majority of resource-poor farmers would be expected to ensue rapidly because their use involves little additional cost, apart from the initial seed outlay. Breeding cultivars resistant to insect pests has also further advantages in that the technical knowledge and the existing farmers' practices may need only some minor modification with the adoption of the new cultivars. Experience shows that seed-based technologies are easier to transfer to small-scale farmers than more complex knowledge-based agronomic and crop protection practices [21]. In addition, host resistance may be used not only as a standalone factor but also as a component of an integrated pest management (IPM) system because it is compatible with cultural, chemical, physical and biological control measures [22].

Thirdly, a long-term use of insecticides may result in the development of resistance by the target pests to the insecticides under question as well as pest resurgence.

Fourthly, as there is no economic threshold level for storage insect pests, unlike field insects, insecticides are applied as a prophylactic measure which further aggravates the problem by destroying the population of natural enemies (predators and parasitoids) of the target insect pests [22]. 
Moreover, legumes are export commodities to several countries and the use of insecticides is strictly governed based on the type allowed and the maximum permissible residual levels in seeds [2].

With the advent of the market for organic agricultural products, cultural practices employing minimum use of external inputs and avoiding application of synthetic fertilizers and pesticides are gaining wider acceptance in a number of developing countries. The use of host resistance is, therefore, the hub of the principle of organic production in terms of both system sustainability and food safety.

\section{Sources of Resistance to Storage Insect Pests}

Breeding progress depends on the magnitude of genetic variability within the germplasm, heritability of the trait under question and the level of selection intensity applied [23]. The higher the levels of these components for a given trait, the higher will be the genetic gain expected from each cycle of selection. In many legumes, different sources of resistance to storage insect pests have been identified from cultivated varieties, germplasm collections and species of wild relatives [10,15,16,22,24].

While genes for complete resistance to insect pests in general and storage insects in particular are of rare occurrence in nature for cultivated species [25], they have often been reported in species of wild relatives for a number of legume crops [10,15-17,24,26]. Nevertheless, a few cases of complete resistance were also reported in cultivated or germplasm collections of haricot bean [26-28], field pea [29,30], cowpea [31-33], black gram [34] and chickpea [13,35]. A number of reports indicate that varieties with improved yield are more susceptible than landraces [6,36]. Absence of positive selection for resistance to storage pests may result in more susceptibility in such otherwise elite cultivars as compared to the landraces [13].

\section{Mechanisms of Seed Resistance to Storage Insect Pests}

A number of specific insect resistance mechanisms have been identified in legumes although they have not yet been widely integrated into mainstream breeding programs [37]. Insect pest resistance in crops generally comprises four important mechanisms (i) antixenosis; (ii) antibiosis; (iii) tolerance; and (iv) escape. Tolerance and escape are resistance mechanisms relevant for field infestations but not for storage insect pests of grain crops. However, the processes of resistance involve morphological, physiological and/or biochemical mechanisms which range from simply minimizing the effect of insect attack to adversely affecting the insects' cellular processes, growth and development [38]. According to Edwards and Singh [37], legumes as a group employ an array of direct and indirect defenses including morphological barriers, secondary metabolites and anti-nutritional compounds. Antibiosis expressed with the adverse effects upon larvae of storage pests feeding on seed of a resistant host plant may also involve morphological, physiological and biochemical features of the host plant or their combination [22]. Antibiosis may lead the insect pest to death.

Green plants utilize principal metabolic pathways and biochemical cofactors for converting carbon dioxide and water to sugars, nitrogen to amino acids, and to synthesize nucleotides, lipids and simple organic acids. These primary plant metabolites serve as the starting materials for the biosynthesis of secondary metabolites (polymers like lignins and tannins, alkaloids, quinines, etc.) that play an important role in the seed defense against insects such as repellents, feeding inhibitors and anti-nutritional factors [22]. In wild species of Phaseolus for instance, arcelin, phytohemagglutinin and 
$\alpha$-amylase inhibitor genes or anti-nutritional proteins collectively called lectins, were identified, cloned and sequenced, and deployed in breeding programs [25,29,37,39]. Lectins are often resistant to proteolytic activity and function by binding to chitin or to carbohydrate targets in the insect's mid gut, thereby blocking nutrient assimilation [37]. The $\alpha$-amylases inhibitor gene from Phaseolus may be the single most studied mechanism providing resistance to legume seed beetles. The $\alpha$-amylases are major digestive enzymes in some bruchids like the adzuki bean beetle that feed on seeds of legumes. To cope with such insect pests, some species of Phaseolus and Pisum have developed seed protection systems involving secondary metabolites like $\alpha$-amylases inhibitors $[29,37,40]$.

Antixenosis refers to non-preference of the insect pest due to unsuitability of the host for oviposition, growth and/or survival due to some morphological or biochemical factors in the host. Morphologically, varieties with smooth, soft and thin seed coats may be more preferable for oviposition than those with rough, hard, wrinkled and somewhat spiny seed coats [13,41], but there is still some controversy and doubt about considering these features as universal indicators of resistance [16,36,42]. For instance, Desroches et al. [6] found that the seed coat in a faba bean (Vicia faba) acts like a physical barrier against penetration by C. chinensis and C. maculatus. They found that only $45-58 \%$ of the neonate larvae perforated through the seed coat to the cotyledons. A similar type of resistance against C. maculatus was also reported on cowpea [43]. On the other hand, Lale and Kolo [36] observed that resistance to C. maculatus in three cultivars of cowpea was conferred mainly by a combination of reduced oviposition and egg-hatching which may be a reflection of chemical rather than physical characteristics of the seed coat. Host plants may also pose nutritional, physiological and ecological hurdles on the insects [22].

\section{Genetics and Breeding of Legume Crops for Resistance to Storage Insects}

The genetic control of resistance to storage insect pests may range from monogenic and oligogenic for insects like $C$. chinensis and $C$. maculatus in mungbean [15,16,33] to polygenic in others like resistance of Pisum fulvum accessions to pea weevil (B. pisorum) [16,17]. The seed $\alpha$-amylase variants of polypeptide inhibitors in haricot bean were also found to be linked with arcelin and inherited as single co-dominant units [44]. Mostly additive and dominant genes may govern storage insect pest resistance in many legume crops $[10,16,17]$ but, in a few cases, cytoplasmic gene effects have also been reported $[10,16,33]$. Consequently, different breeding methods may be required to be followed in different cases. For instance, when seed resistance is under cytoplasmic gene effects, the backcross method is more relevant to transfer the cytoplasm from one parent into another, using the parent from which the cytoplasm is to be transferred as the female [38]. In such a case, allowances for one more generation is also required in order to test the preceding generation, i.e., $\mathrm{F}_{3}$ seeds from $\mathrm{F}_{2}$ plants are required to test $\mathrm{F}_{2}$ segregation.

The major sources of genetic variation for improving resistance against storage insect pests, like many other biotic stresses, include germplasm collections from local sources, introduction and acquisition of germplasm from exotic sources and recombinants resulting from crossings of selected parents of all sources. The basic selection methods (i.e., mass, bulk, pedigree and backcross methods, etc. or their modifications) may be applied depending on the mode of inheritance and the number of genes controlling resistance under a given condition. 
Conversion of the otherwise well-adapted varieties into their resistant counterparts could be the first priority in achieving agronomically desirable varieties that are resistant to storage insects within a short time. Introductions from exotic sources maybe received at their earlier filial generations to select better-performing segregants under managed infestation and screening in controlled environments or after they attain homogeneity as the case may be. The efforts to be made and the steps to be followed in breeding for resistance against storage insect pests may vary with the source of initial genetic material (i.e., whether from primary, secondary or tertiary gene pools) and the breeding status on receipt by the breeder. Genetic recombination and selection of desirable segregants would be more successful as it goes from tertiary to primary gene pools [38]. Even though a one-size-fits-all scheme may be an oversimplification of the more complicated situation, a general hypothetical representation of germplasm flow chart and the logical steps to be followed in breeding for resistance to storage insects starting from germplasm acquisition to yield testing may be as suggested in Figure 1.

Figure 1. Flow chart of logical steps to be followed in breeding food legumes for resistance to storage insect pests.

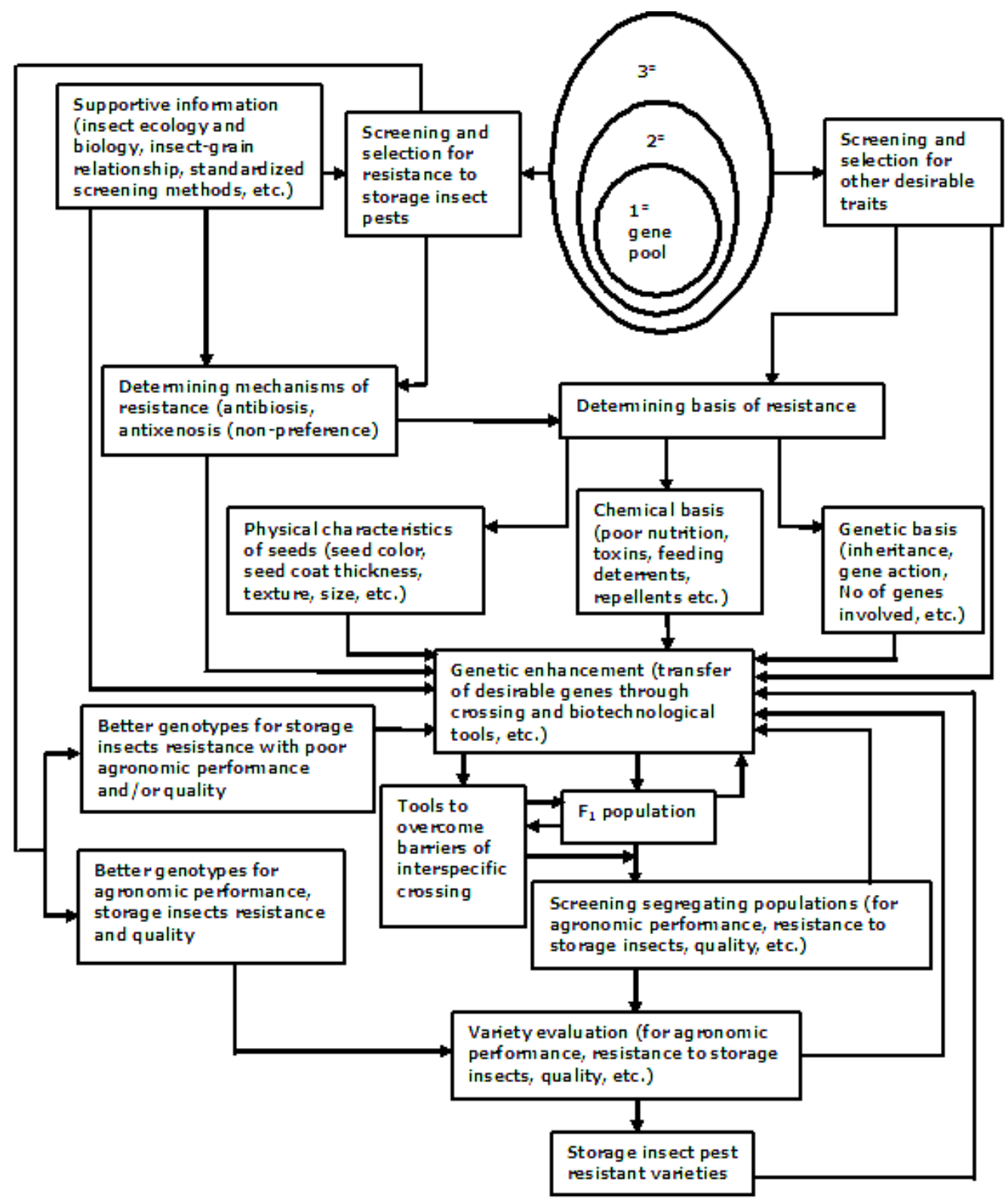




\section{Potential of Breeding Legumes for Resistance to Storage Insect Pests}

Breeding legume crops for resistance to storage insect pests is likely to be successful as a number of studies demonstrated the existence of genetic variation in landraces, cultivated varieties and their wild relatives [10,13,15-17,24,30]. From an evaluation of a core collection of Vigna species, for instance, a high level of bruchid resistance was reported [39] particularly among the cultivated rice bean (Vigna umbellata). This may be considered to be potentially the most useful as many of the cultivated accessions showed complete resistance to the bruchids [5,10]. As resistance, in a number of cases, was found to be controlled mostly by a single or a few genes in many legume crops $[10,16,17]$, transferring such resistance genes to commercial cultivars would be possible even with the conventional breeding approaches [16].

Indicative progress has been achieved from genetic improvements in some legumes for resistance to storage insects particularly with the efforts made by some of the international research institutions under the Consultative Group for International Agricultural Research (CGIAR). For instance, the International Center for Tropical Agriculture (CIAT) has developed a series of haricot bean genotypes with arcelin-based resistance to Zabrotes subfasciatus [45], the initial gene source being a wild accession, G02771 [46]. The International Institute of Tropical Agriculture (IITA) has also developed a number of cowpea genotypes conferring trypsin-based resistance to C. maculatus [47], the source accession, TVu 2027, being from cultivated species [3]. Genetic materials derived from both sources have, one way or another, been utilized by the national breeding programs in many countries like Nigeria [36,43], Brazil [48], Japan [40], United Kingdom [49] and Ethiopia [50].

It is obvious that the conventional breeding methods should be supported by molecular approaches such as identification of molecular marker(s) linked to insect resistance. This will minimize excessive reliance on phenotypic traits for screening with bioassay tests using controlled pest infestation on seeds [32], and thus increase breeding efficiency and precision. While conventional breeding will continue to have a valuable role in providing storage insect pest resistant cultivars of many legume crops, it appears that in some systems there will continue to be barriers to achieving resistance using this approach. Molecular tools give us an opportunity to develop genotypes that carry resistance traits [51] and these tools have been utilized in DNA fingerprinting for identification of cultivars, marker assisted selections and, to a limited extent, for genetic modification in breeding for insect resistance [25,51]. Problems associated with the need for long cycles of backcrossing with the conventional breeding method have already been resolved [52]. For example, the application of marker-assisted selection in haricot bean to transfer resistance genes to Zabrotes subfasciatus from a wild background into elite cultivars through backcrossing at CIAT was proved to be simpler and more effective than the conventional methods [53].

There are opportunities arising from our growing understanding of the signaling mechanisms that condition responses in plants to insect attack [37]. Practical examples of advanced-level use of biotechnology for breeding resistant varieties to field insect pests include the transfer of the gene for insect resistance (cry gene) from a soil-born bacterium (Bacillus thuringiensis) into the cultivated crops like cotton, maize, potato and soybean [54]. Even though only cry genes from $B$. thuringiensis have been commercially exploited so far for this purpose, many other genes of bacterial, plant, or other origins have been successfully used to confer storage insect pest resistance [51,55]. For instance, the 
transfer of a gene for $\alpha$-amylase inhibitor-1 ( $\alpha \mathrm{AI})$ from haricot bean (Phaseolus vulgaris) to field pea (Pisum sativum) was successful in effectively protecting the latter from pea weevil (Bruchus pisorum) [56].

Current developments in the use of biotechnological tools against storage insect pests in food legumes include: identification of sources of resistance [10,15-17,24,39,57,58], locating the resistance genes in cultivated and wild species, developing and mapping genetic markers $[10,15,17,58]$ and cloning genes, few as they may be [17,25,59]. Attempts for genetic transformation started by the pioneering works of Shade et al. [60] in field pea have been continued in a number of pulses like haricot bean, field pea, chickpea, groundnut, lentil, pigeon pea, cow pea and faba bean $[19,29,51,55]$. The effectiveness of marker-assisted selection for developing varieties resistant to storage insect pests in a number of legumes is asserted by some workers [15,17]. Even with the possibilities of successfully breeding varieties of food legumes with resistance against storage insect pests, certain technical limitations still apply as will be discussed in the following section.

\section{Limitations of Breeding Legume Crops for Storage Insect Pest Resistance}

Breeding efforts have been underway for a long period of time to develop varieties with resistance to storage insect pests [22,36]. However, it is hardly possible to say that these efforts have reached their desired peaks of fruition because of a number of specific limitations impeding major advances [4]. Specific legume crops suffer specific problems but, in the following sections, we will focus on general problems common to many legume crops.

\subsection{Methodological Limitations}

The breeding methods proved effective for resistance against field insects pests appear to be difficult to directly apply to breeding against storage insect pests. The actual stress for targeted selection in the laboratory may be created by infestation of the seeds with eggs, larvae or adults depending on specific situations [22]. Optimum environmental conditions, particularly temperature and relative humidity, can also be simulated. For instance, optimization of the test environment particularly of temperature level under regulated conditions enabled identification of resistant cowpea genotypes with better precision [31,32]. Recent collections of accessions of crops or their wild relatives may provide solutions to the problem of limited genetic resources for resistance breeding to storage insects in legume crops [30]. Nevertheless, resistance combined with desirable agronomic characteristics for direct use is usually of rare occurrence in nature and it may also be difficult to increase the frequency of resistant genotypes through artificial recombination [30,37,61].

Direct selections of both early and late generations of segregating populations need to have the necessary situations created for the expression of resistance for easy identification. The most important limitation implicated here is that the methods of both artificial bioassays and biochemical tests that the breeder has to employ to identify resistance in each and every segregant plant, are expensive with regard to technical and resource requirements. Furthermore, indirect selections using easily observable morphological traits, like seed texture, associated with resistance $[13,41]$ may not always be consistent $[16,36,42]$. The genetic expression of different traits and the extent and pattern of their relationship may also vary with changes in the environment [62]. Not only secondary traits but resistance as a primary trait of interest may show high interaction between environment and seed 
variety and between environment and pest population [49]. Advancing all segregants without high selection pressure at the early stages would result in an unmanageable population size for screening at the later stages. Early generation selection based on other desirable agronomic characters, followed by testing for resistance at advanced level, cannot make up for the useful genetic variation that might have already been lost when a large number of genotypes that would have been resistant were discarded at the earlier stages. These same limitations encountered with screening segregating materials may also hold true for screening germplasm collections in search of resistant individuals. Therefore, more reliable secondary traits must be sought for effective selection. These must be genetically variable, highly heritable, easily observable in the field or in the store and positively associated with resistance (negatively associated with susceptibility) to storage insects without compromise of quality of produce.

Molecular techniques have also a lot of technical limitations as for instance, efficient methods of introducing foreign genes into desirable genotypes are still lacking [63]. In Australia an $\alpha$-amylase inhibitor gene was successfully transferred from Phaseolus vulgaris into a non-native host Pisum sativum. Although transformation of the latter, in terms of resistance gene was successful, consumption of the transgenic Pisum resulted in an inflammatory response in the experimental mice [56]. Chickpeas transformed for a bean $\alpha$-amylase inhibitor were also found to strongly inhibit the development of storage pests particularly Callosobruchus maculatus and C. Chinensis [63,64] but food safety is untested, although the $\alpha$ - amylase inhibitor is heat labile and denatured by cooking [38]. Nevertheless, single-gene resistances may need supplementation by other methods thus avoiding the selection pressure that is likely to cause rapid emergence of bruchid strains that are not affected by the inhibitor [63]. The use of transgene from wide hybridization, found to be so effective, could result in selection pressure causing rapid emergence of pest strains not affected by host resistance mechanisms. An example of which is the production of inhibitors [29]. For each defense mechanism by host plants, there is a tendency that the insects also evolve to virtually develop different counteracting mechanisms enabling them to overcome the specific mechanism poised by the host plant. For example, the ability to produce enzymes which can detoxify otherwise toxic food or the avoidance of food poisoning by some of the insects [22]. The methods to overcome such complicated interactions are limited.

\subsection{Biotypic Variation}

Breeding for insect pest resistance in general is complicated by the genetic variability of the pest population. Biotypes of each species may differ in their ability to infest or attack varieties of the same host species. Cultivars resistant to one biotype may fail to resist another biotype and it will be challenging for plant breeders to develop cultivars that can universally resist all possible combination of biotypes. For instance, laboratory studies on geographically distinct populations of C. maculatus have repeatedly highlighted significant intra-specific variations in performance on resistant cowpeas [49], indicating that the effectiveness of a resistant variety in one geographical location cannot necessarily be taken as an indication of its effectiveness in other locations. While breeding for resistance against a single biotype itself may be sufficient to complicate the task of plant breeding against insects, it can be worsened by the existence of multiples of biotypes at a point in time.

True resistance-breaking biotypes of many insect pests have also been reported, but resistant crop varieties have usually provided a good level of protection as the insects have less chance of mutation 
compared to disease pathogens [38]. Nevertheless, care must still be taken that biotypes of each species may differ in their ability to infest or attack varieties of the same host species as mentioned above. A crop cultivar exposed to one biotype may at the same time be faced with another biotype. In such cases, incorporation of different resistance genes into the same cultivar (i.e., gene pyramiding) to control the different biotypes is possible as has been demonstrated with the breeding of mungbean for multiple resistances to different biotypes of bruchids $[15,16]$. The incorporation of vertical (monogenic) resistance with polygenic resistance [52] and the pyramiding (stacking) of genes for vertical resistance against a number of pathogenic races (combining several genes for vertical resistance into a single genotype through a "parallel" recombination strategy) were suggested to counter multiple races of diseases $[52,65,66]$. However, the relevance of this approach for breeding cultivars resistant to insect pests may need to be investigated.

\subsection{Undesirable Genetic Linkages}

Achieving pest resistance without reducing agronomic quality has been among technical challenges of significant concern [37]. Even though it is evident that certain level of genetic diversity within crop plants and a significant level in wild germplasm may be available, proper exploitation, particularly from the latter, is limited by the existence of undesirable genetic linkages [25,37] whereby genes for desirable and undesirable characters would be co-inherited. Consequently, breeding for resistance against storage insect pests using wild relatives as gene sources may improve resistance but often reduces the quality of the produce or may even make it unfit for consumption [38]. In addition, varieties carrying genes for insect pest resistances transferred from related wild species may be low yielders with inferior quality. Wild species have several defects not only in terms of agronomic performance, but also in terms of food safety [15,16,39,57]. It may be particularly difficult to breed for pest resistance when the mechanism of resistance in itself reduces crop quality. This can be true for many physical resistance mechanisms including pod thickness (e.g., pea weevil resistance), and for chemical resistance when the compounds involved are also toxic to man (alkaloids in lupins for example). The problem of genetic drag may be particularly serious when the resistance traits sought are under polygenic control or have low dominance. This would result in many undesirable qualities being introduced along with the desired trait during the breeding process [37].

Genetic linkage between genes for desirable and undesirable characters could be broken and the linked genes may be separated when there is crossing-over between homologous chromosomes during meiosis. The breeder would, therefore, have to grow a large number of $F_{2}$ populations in order to increase the level of recovery of new recombinants as a result of possible crossing-over. A modified recurrent selection procedure was also used by CIAT to successfully overcome this problem and to improve resistance and tolerance to the leafhopper, a field insect, in common beans [37]. Backcross breeding could be another approach to minimize such deleterious effects of linkage drag.

\subsection{Lack of Inter-Specific Cross-Compatibility}

Inter-specific hybridization may normally be made to transfer specific characters like pestresistance traits from wild species to the cultivated ones. Nevertheless, the transfer of genes governing pest resistance in general from wild relatives to cultivated varieties presents inter-specific 
cross-incompatibility which may not be easy to overcome. In general, species with close taxonomical relations are expected to intercross more easily than those more distantly related. For instance, very low cross compatibility was reported between Vigna umbellata and the adzuki bean (V. angularis) and between $V$. radiata var. sublobata and $V$. mungo var. silvestris [10]. In some cases, where inter-specific cross-incompatibility is not a problem, failure of zygotic formation (failure of fertilization) and development or failure of $F_{1}$ germination may be encountered due to existence of lethal genes, genotypic disharmony (genetic imbalance in the resultant hybrid) between the two parental genomes, chromosome elimination (mitotic irregularities), and incompatible cytoplasm or endosperm abortion [38].

The recovery of inter-specific hybrids may normally be improved by making sufficiently large number of crosses from given parents. Obtaining $\mathrm{F}_{1}$ may not be possible at all when distant species, particularly those with different ploidy levels, are crossed [38]. For instance, even though many accessions of the cultivated rice bean ( $V$. umbellata) showed complete resistance to bruchids, the transfer of bruchid resistance from this cultivated species to susceptible adzuki bean was found to be difficult due to cross-incompatibility between the two species [10]. In such cases, mismatches in chromosome number may be adjusted by increasing or reducing chromosome number in one of the parents or their $F_{1}$ crosses or both or by using another bridging species. When two species cannot be crossed directly, the third species which is compatible with both parental species may be used as a bridge in such a way that the bridge species is first crossed to one of the parental species and then the resulting $\mathrm{F}_{1}$ will be crossed to the other parental species. For example, species of the $V$. minima, $V$. riukiuensis and $V$. nakashimae have been suggested as the most suitable bridging species between $V$. umbellata and $V$. angularis to transfer bruchid resistance from $V$. umbellata to $V$. angularis [10,39]. Therefore, $V$. nakashimae, that crosses with both $V$. umbellata and $V$. angularis without the need for embryo rescue could be used as a bridging species [10].

Failure of seed setting in inter-specific crosses may also be overcome by the use of embryo culture techniques [38]. Ease of hybridization among $V$. angularis, $V$. nakashimae and $V$. Umbellate is so different that crosses between $V$. angularis and $V$. umbellata require embryo rescuing as there is a high level of abnormality in the segregating populations while the hybrids between $V$. umbellata and $V$. nakashimae may not require such embryo rescuing [67].

\subsection{Limited Knowledge of Genetic Bases of Resistance}

Even though possibilities for genetic improvement of resistance to storage insects have been shown by many authors, including at molecular level [10,13,15-17], better understanding of the genetic basis of resistance to storage insect pests is of particular importance to breeders. Nevertheless, generation of information related to genetics of resistance to storage insects in crop cultivars has received little attention compared to resistance even to field insects. When available, the information often suggests limited success. For instance, genetic analysis of pod and seed resistance to pea weevil (B. pisorum) in an inter-specific cross between Pisum sativum $\times P$. fulvum showed low heritability values implying that only a limited success is expected from the breeding program [68].

Entomologists have investigated morphological and biochemical bases of resistance to storage insect pests $[13,25,28,29,42]$. Nevertheless, failures arise in many cases because proper links have not 
been established between entomologists and geneticists or breeders in identifying the resistance mechanisms and introducing the genes controlling them into commercial lines [37]. The efforts dedicated thus far to generating baseline information do not provide full insight into the whole plant-insect and environment relations and functioning systems and thus into establishing the exact genetic control mechanisms for host resistance to storage pests in different legume crops. Further investigation of these relationships [15] will hasten identification of various sources of seed weevil resistance, thus broadening the genetic base [69].

\section{Summary and Conclusions}

The preceding discussion shows that storage insect pests are among the real challenges to agricultural researchers in general and to entomologists and plant breeders in particular. There is no doubt that the breeding of productive genotypes with better genetic resistance to storage insect pests could be one of the alternatives to address problems of storage insect pests in food legumes. With due respects to the dedicated efforts made and the achievements so far by pioneering institutions like CIAT and IITA, it has been clearly shown that genetic research made hitherto to develop crop cultivars resistant to storage insect pests has had only limited success on a global scale in terms of the desired crop varietal breakthrough even relative to the efforts made for field insect pests [4].

However, it is generally possible, to say that the future of breeding for resistance against storage insects in food legumes is not at all bleak although there are some inevitable challenges. Examples of which are problems related to lack of efficient selection strategy, biotypic variation, undesirable genetic linkages or linkage drag, inter-specific cross-incompatibilities, proper gauging of selection pressure for new biotypes and breakdown of resistance and lack of knowledge of genetic bases of resistance. The current methods and approaches employed to breed for resistance against storage insect pests, particularly those meant for transferring resistance genes from wild relatives to cultivars, need systematic refinement and optimization under specific situations. This, however, is assumed to be a possibility with the current pace of advancement in genetics, plant breeding and entomology coupled with strong interdisciplinary collaborations.

Resistance to most of the storage insect pests is of rare natural occurrence in the cultivated species for direct exploitation, but may sometimes be revealed in the screening of very large numbers of landraces. Such an example is the identification of Tvu 2027 cowpea among thousands of accessions [45]. Consequently, it is appropriate to screen and evaluate a broad array of wild species in search of these genes. In the future, special attention should be paid to producing plants resistant to storage insect pests which can simultaneously hinder the development of resistance by the insects under question as occurs with the $\alpha$-amylase inhibitor [32]. One possible way to achieve this is by stacking two or more resistance genes with different modes of action into a single genotype [55]. It is believed that molecular approaches are promising to provide novel strategies for transferring alien gene(s) of resistance between distant species [37], which is hardly possible using the conventional techniques [39]. Nevertheless, as varietal breakthroughs against storage insect pests of food legumes are still far from fruition, whatever level of genetic resistance achieved so far must be integrated with other cultural, chemical and biological control methods available to obtain immediate synergetic effects. 
Furthermore, this paper also revealed the need that entomologists and plant breeders should exert their efforts in a concerted, balanced and mutually complementary manner rather than exclusively and independently in order to achieve success in changing the responses of food legumes to storage insect pests. Boosting yield potential with genetic improvement of legumes as with any other crop is essential but, at the same time, with the same genetic tools it is also necessary to safeguard the produce from yield-reducing storage insect pests. It is not a matter of choice but a necessity that requires equal priority particularly in the Tropics and Subtropics where the highest loss is manifested but, unfortunately, where many poor people have no adequate sources of high protein foods. This is a challenge to the respective researchers; and yet it is no simple challenge!

\section{Acknowledgements}

The authors would like to thank Nigussie Alemayehu, FAO Expert, Agricultural Rural Capacity Building Project, Ethiopian Program, for a professional edition of the draft of the manuscript. They are also highly indebted to Zerihun Tadele for kindly paying the publication fee for this article from Tef Improvement Project, the University of Bern, Switzerland.

\section{References and Notes}

1. CIAT (Centro Internacional de Agricultura Tropical). Main Insect Pests of Stored Beans and Their Control: A Study Guide, Series 04EB-05.03, Apartado Aéreo 6713; CIAT (Centro Internacional de Agricultura Tropical): Cali, Colombia, 1986.

2. Evans, D.E. Stored Product. In Integrated Pest Management; Burn, A.J., Cooker, T.H., Jepson, P.C., Eds.; Academic Press: London, UK, 1987; pp. 425-455.

3. IITA. Joint Project 31-Semi-Arid Food Grain Research and Development (SAFGRAD). Final Report, Phase I. The International Institute of Tropical Agriculture (IITA): Ibadan, Nigeria, 1986.

4. Bushara, A.G. Insect Depredation during Storage. In World Crops: Cool Season Food Legumes; Summerfield, R.J., Ed.; Kluwer: Dordrecht, the Netherlands, 1988; pp. 367-378.

5. Kashiwaba, K.; Tomooka, N.; Kaga, A.; Han, O.K.; Vaughan, D.A. Characterization of resistance to three bruchid species (Callosobruchus spp., Coleoptera, Bruchidae) in cultivated rice bean (Vigna umbellata). J. Econ. Ent. 2003, 96, 207-213.

6. Desroches, P.; Elshazly, E.; Mandon, N.; Duc, G.; Huignard, J. Development of Callosobruchus chinensis (L.) and C. maculatus (F.) (Coleoptera: Bruchidae) L. in seeds of Vicia faba differing in tannin, convicine and vicine Contents. J. Stored Prod. Res 1995, 31, 83-89.

7. Ali, K.; Habtewold, T. Research on Insect Pests of Cool-Season Food Legumes. In Cool-Season Food Legumes of Ethiopia, Proceedings of the First National Cool-Season Food Legumes Review Conference, Addis Ababa, Ethiopia, 16-20 December 1993; Tilaye, A., Bejiga, G., Saxena, M.C., Solh, M.B., Eds.; ICARDA/IAR: Aleppo, Syria, 1994; pp. 367-396.

8. Damte, T.; Dawd, M. Cickpea, lentil and grass pea insect pest research in Ethiopia: A review. In Food and Forage Legumes of Ethiopia: Progress and Prospects, Proceedings of a Workshop on Food and Forage Legumes, Addis Ababa, Ethiopia, 22-26 September 2003; Ali, K., Keneni, G., Ahmed, S., Malhotra, R., Beniwal, S., Makkouk, K., Halila, M.H., Eds.; ICARDA: Aleppo, Syria, 2006; pp. 260-273. 
9. Boeke, S.J.; Baumgarta, I.R.; Jvan Loona, J.A.; van Huisa, A.; Dickea, M.; Kossoub, D.K. Toxicity and repellence of African plants traditionally used for the protection of stored cowpea against Callosobruchus maculatus. J. Stored Prod. Res. 2004, 40, 423-438.

10. Somta, P.; Talekar, N.S.; Srinives, P. Characterization of Callosobruchus chinensis (L.) resistance in Vigna umbellata (Thunb.) Ohwi \& Ohashi. J. Stored Prod. Res. 2006, 42, 313-327.

11. Aslam, M.; Shaheen, F.A.; Abbas, M.A.; Saba, A. Management of Callosobruchus chinensis Linnaeus through use of resistance in stored chickpea varieties. World J. Agri. Sci. 2006, 2, 82-84.

12. Haile, A. On-farm storage studies on sorghum and chickpea in Eritrea. Afr. J. Biotechnol. 2006, 5, 1537-1544.

13. Shaheen, F.A.; Khaliq, A.; Aslam, M. Resistance of chickpea (Cicer arietinum L) cultivars against pulse beetles. Pak. J. Bot. 2006, 38, 1224-1244.

14. Sithanantham, S.; Raga Rao, G.V. Research needs in pest management for improved productivity and sustainability of food legume crops in Eastern Africa. In Food and forage legumes of Ethiopia: Progress and Prospects, Proceedings of a Workshop on Food and Forage Legumes, Addis Ababa, Ethiopia, 22-26 September 2003; Ali, K., Keneni, G., Ahmed, S., Malhotra, R., Beniwal, S., Makkouk, K., Halila, M.H., Eds.; ICARDA: Aleppo, Syria, 2006; pp. 238-246.

15. Chen, H.M.; Liv, C.A.; Kuo, C.G.; Chien, C.M.; Sun, H.C.; Huang, C.C.; Lin, Y.C.; Ku, H.M. Development of molecular marker for a bruchid (Callosobruchus chinensis) resistance gene in mungbean. Euphytica 2007, 157, 113-122.

16. Somta, P.; Ammaranan, C.; Ooi, P.A.C.; Srinives, P. Inheritance of seed resistance of bruchids in cultivated mungbean (Vigna radiate L. Wilezek). Euphytica 2007, 155, 47-55.

17. Somta, P.; Kaga, A.; Tomooka, N.; Isemura, T.; Vaughan, D.A.; Srivines, P. Mapping of quantitative trait loci for a new source of resistance to bruchids in the wild species Vigna nepalens Tateishi \& Maxted (Vigna subgenus Ceratotropis). TAG Theor. Appl. Genet. 2008, 117, 621-628.

18. Cribb, J. The Coming Famine: The Global Food Crises and What We Can Do to Avoid It; CSIRO Publishing: Collingwood, Victoria,, Australia, 2010.

19. Ignacimuthu, S.; Prakash, S. Agrobacterium-mediated transformation of chickpea with $\alpha$ - amylase inhibitor gene for insect resistance. J. Biol. Sci. 2006, 31, 339-345.

20. De Boef, W.S.; Berg, T.; Haverkort, B. Crop Genetic Resources. In Biotechnology: Building on Farmers' Knowledge; Bunders, J., Haverkort, B., Hiemstra, W., Eds.; Macmillan: London, UK, 1996; pp. 103-128.

21. Edmeades, G.O.; Bolanos, J.; Banziger, M.; Ribaut, J.M.; White, J.W.; Reynolds, M.P.; Lafitte, H.R. Improving crop yields under water deficits in the tropics. In Crop Productivity and Sustainability - Shaping the Future, Proceedings of the 2nd International Crop Science Congress, New Delhi, India, 14-17 November 1996; Chopra, V.L., Singh, R.B., Varma, A., Eds.; Oxford and IBH: New Delhi, India, 1998; pp. 437-451.

22. Panda, N.; Khush, G.S. Host Plant Resistance to Insects. CAB International in association with International Rice Research Institute (IRRI): Biddles Ltd.: Guildford, UK, 1995.

23. Falconer, D.S. Introduction to Quantitative Genetics, 3rd ed.; Longman: London, UK, 1989.

24. Ku-Hwan, L.; Seung-Keun, J.; Sang-II, P.; Beom-Heon, S.; Yong-Gu, C.; Hong-Sig, K. Agronomic characteristics of resistant mungbean to Callosbruchus chinensis. J. Agri. Sci. 2002, $19,41-52$. 
25. Acosta-Gallegos, J.A.; Kelly, J.D.; Gepts, P. Prebreeding in common bean and use of genetic diversity from wild germplasm. Crop Sci. 2008, 48, 3-16.

26. Ishimoto, M.; Suzuki, K.; Iwanaga, M.; Kikuchi, F.; Kitamaru, K. Variation of seed $\alpha$-amylase inhibitors in the common bean. Theor. Appl. Genet. 1995, 90, 425-429.

27. Ishimoto, M.; Sato, T.; Chrispeels, M.J.; Kitamaru, K. Bruchid resistance of transgenic adzuki bean expressing seed $\alpha$-amylase inhibitor of common bean. Ent. Exp. Appl. 1996, 79, 309-315.

28. Goossens, A.; Quintero, C.; Dillen, W.; De Rycke, R.; Valor, J.F.; de Clercq, J.; Montagu, M.V.; Cardona, C.; Angenon, G. Analysis of bruchid resistance in the wild common bean accession G02771: No evidence for the insecticidal activity of arcelin 5. J. Exp. Bot. 2000, 51, 1229-1236.

29. Morton, R.L.; Schroeder, H.E.; Bateman, K.S.; Chrispeels, M.J.; Armstrong, E.; Higgins, T.J.V. Bean $\alpha$-amylase inhibitor 1 in transgenic peas (Pisum sativum) provides complete protection from pea weevil (Bruchus pisorum) under field conditions. Proc. Natl. Acad. Sci. USA 2000, 97, 3820-3825.

30. Clement, S.L.; Hardie, D.C.; Elberson, L.R. Variation among Accessions of Pisum fulvum for resistance to pea weevil. Crop Sci. 2002, 42, 2167-2173.

31. Redden, R.J. The inheritance of seed resistance to Callosobruchus rnaculatus F. in cowpea (Vigna unguiculata L. Walp.). II. Analyses of percentage emergence and emergence periods of bruchids in F4 seed generation of two reciprocal crosses. Aust. J. Agric. Res. 1983, 34, 697-705.

32. Redden, R.J.; McGuire, J. The genetic evaluation of bruchid resistance in seed of cowpea. Aust. J. Agric. Res. 1983, 34, 707-715.

33. Redden, R.J.; Dobie, P.; Gatehouse, A.M.R. The inheritance of seed resistance to Callosobruchus rnaculatus F. in cowpea (Vigna unguiculata L. Walp.). I. Analyses of parental, $\mathrm{F}_{1}, \mathrm{~F}_{2}, \mathrm{~F}_{3}$ and backcross seed generations. Aust. J. Agric. Res. 1983, 34, 681-695.

34. Dongre, T.K.; Pawar, S.E.; Thakare, R.G.; Harwalker, M.R. Identification of resistant sources to cowpea weevil (Callosobruchus maculatus (F.)) in Vigna sp. and inheritance of their resistance in black gram (Vigna mungo var. mungo). J. Stored Prod. Res. 1996, 32, 201-204.

35. Pacheco, I.A.; Bolonhezi, S.; Sartori, M.R.; Turatti, J.M.; Paula, D.C.; de Lourencao, A.L. Resistance to bruchids, fatty acid composition and grain texture in genotypes of chickpea. Bragantia 1994, 53, 61-74.

36. Lale, N.E.S.; Kolo, A.A. Susceptibility of eight genetically improved local cultivars of cowpea to Callosobruchus maculatus F. (Coleoptera: Bruchidae) in Nigeria. Int. J. Pest Man. 1998, 44, 25-27.

37. Edwards, O.; Singh, K.B. Resistance to insect pests: What do legumes have to offer? Euphytica 2006, 147, 273-285.

38. Singh, B.D. Plant Breeding: Principles and Methods; Kalyani Publishers: New Delhi, India, 2002.

39. Tomooka, N.; Kashiwaba, K.; Vaugham, D.A.; Ishimoto, M.; Egawa, Y. The effectiveness of evaluating wild species: Searching for sources of resistance to bruchid beetles in the genus Vigna subgenus Ceratotropis. Euphytica 2000, 115, 27-41.

40. Yamada, T.; Ikeda, M.; Kobayashi, M.; Hattori, K. Cloning and expression of a cDNA encoding larval $\alpha$-amylase of adzuki bean weevil, Callosobruchus chinensis. J. Insect Biotechnol. Sericol. 2003, 72, 139-148. 
41. Ahmed, K.; Khalique, F.; Afzal, M.; Tahir, M.; Malik, B.A. Variability in chickpea (C. arietinum L.) genotypes for resistance to Callosobruchus maculates F. (Bruchidae). J. Stored Prod. Res. 1989, 25, 91-99.

42. Srinivasan, T.; Durairaj, C. Biochemical basis of resistance to in rice bean Vigna umbellata Thunb. (Ohwi and Ohashi) against Callasobruchus maculatus F. J. Entomol. 2007, 4, 371-378.

43. Edde, P.E.; Amatobi, C.A. Seed coat has no value in protecting cowpea seed against attack by Callosobruchus maculatus (F.) J. Stored Prod. Res. 2003, 39, 1-10.

44. Suzuki, K.; Ishimoto, M.; Iwanaga, M.; Kikuchi, F.; Kitamura, K. Inheritance of seed $\alpha$-amylase inhibitor in the common bean and genetic relationship to arcelin. Theor. Appl. Genet. 1995, 90, 762-766.

45. Singh, B.B.; Singh, S.R. Breeding for Bruchid resistance in cowpea. Research Report No. 5. The International Institute of Tropical Agriculture (IITA): Ibadan, Nigeria, 1992; pp. 1-5.

46. Schoonhoven, A.V.; Cardona, C.; Valor, J. Resistance to the bean weevil and the Mexican bean weevil (Coleoptera: Bruchidae) in non-cultivated bean accessions. J. Econ. Ent. 1983, 76, 1255-1259.

47. Singh, B.B.; Singh, S.R.; Adaji, O. Bruchid resistance in cowpea. Crop Sci. 1985, 25, 736-739.

48. Sales, M.P.; Pimenta, P.P.; Paes, N.S.; Grossi-de-Sá, M.F.; Xavier-Filho, J. Vicilins (7S storage globulins) of cowpea (Vigna unguiculata) seeds bind to chitinous structures of the midgut of Callosobruchus maculatus (Coleoptera: Bruchidae) larvae. Braz. J. Med. Biol. Res. 2001, 34, 27-34.

49. Appleby, J.H.; Credland, P.F. Environmental conditions affect the response of West African Callosobruchus maculatus (Coleoptera: Bruchidae) populations to susceptible and resistant cowpeas. J. Stored Prod. Res. 2004, 40, 269-287.

50. Assefa, T.; Battisti, A.; Cardona, C.; Blair, M.; Beebe, S.; Lucchin, M. Evaluation of advanced breeding lines of common bean (Phaseolus vulgaris L.) for resistance to the Mexican bean weevil (Zabrotes subfasciatus) and yield potential. Pest. Mgt. J. Eth. 2009, 13, 22-32.

51. Ranjekar, P.K.; Patankar, A.; Gupta, V.; Bhatnagar, R.; Bentur, J.; Kumar, P.A. Genetic engineering of crop plants for insect resistance. Curr. Sci. 2003, 84, 321-329.

52. Higgins, V.J.; Lu, H.; Xing, T.; Gelli, A.; Blumwald, E. The gene-for-gene concept and beyond: Interactions and signals. Can. J. Plant Pathol. 1999, 20, 150-157.

53. Blair, M.W.; Fregene, M.A.; Beebe, S.E.; Ceballos, H. Marker-Assisted Selection in Common Bean and Cassava. In Marker-Assisted Selection: Current Status and Future Perspectives in Crops, Livestock, Forestry and Fish; Ruane, B.D., Sonnino, S.A., Dargie, J.D., Eds.; Food and Agriculture Organization of the United Nations (FAO): Rome, Italy, 2007; pp. 81-115.

54. Bowman, D.T.; May, O.L.; Creech, J.B. Genetic uniformity of the U.S. upland cotton since the introduction of transgenic cottons. Crop Sci. 2003, 43, 515-518.

55. Keresa, S.; Grdisa, M.; Baric, M.; Baric, J.I.; Marchetti, S. Transgenic plants expressing insect resistance genes. Sjemenarstvo 2008, 25, 139-153.

56. Prescott, V.E.; Campbell, P.M; Moore, A.; Mattes, J.; Rothenberg, M.E.; Foster, P.S.; Higgins, T.J.V.; Hogan, S.P. Transgenic expression of bean $\alpha$-amylase inhibitor in peas results in altered structure and immunogenicity. J. Agric. Food Chem. 2005, 53, 9023-9030. 
57. Tomooka, N.; Lairungreang, C.; Nakeeraks, P.; Egawa, Y.; Thauarasooks, C. Development of bruchid resistant mungbean line using wild mungbean germplasm in Thailand. Plant Breed. 1992, 109, 60-66.

58. Young, N.D.; Kumar, L.; Menancio, H.D.; Talekar, N.S.; Shanmugasundarum, S.; Kim, D.H. RFLP mapping of a major bruchid resistance gene in mungbean (Vigna radiata L. Wilezek). Theor. Appl. Genet. 1992, 84, 839-844.

59. Popelka, J.C.; Terryn, N.; Higgins, T.J.V. Gene technology for grain legumes: Can it Contribute to the food challenge in developing countries? Plant Sci. 2004, 167, 195-206.

60. Shade, R.E.; Schroeder, H.E.; Pueyo, J.J.; Tabe, L.M.; Murdock, L.L.; Higgins, T.J.V.; Chrispeels, M.J. Transgenic pea seeds expressing the a-amylase inhibitor of the common bean are resistant to bruchid beetles. Biotechnology 1994, 12, 793-796.

61. Nishizawa, K.; Teraishi, M.; Utsumi, S.; Ishimoto, M. Assessment of the importance of $\alpha$-amylase inhibitor-2 in bruchid resistance of wild common bean. Theor. Appl. Genet. 2007, 14, $755-764$.

62. Lawes, D.A.; Bond, D.A.; Poulsen, M.H. Classification, Origin, Breeding Methods and Objectives. In The Faba Bean (Vicia faba L.); Hebblethwaite, P.D., Ed.; The Cambridge University Press: Cambridge, UK, 1983; pp. 23-76.

63. Romeis, J.; Sharma, H.C.; Sharma, K.K.; Das, S.; Sarmah, B.K. The potential of transgenic chickpeas for pest control and possible effects on non-target arthropods. Crop Prot. 2004, 23, 923-938.

64. Sarmah, B.K.; Moore, A.; Tate, W.; Molvig, L.; Morton, R.L.; Rees, D.P.; Chiaiese, P.; Chrispeels, M.J.; Tabe, L.M.; Higgins, T.J.V. Transgenic chickpea seeds expressing high levels of a bean $\alpha$-amylase Inhibitor. Mol. Breed. 2004, 14, 73-82.

65. Sharma, J.R. Principles and Practice of Plant Breeding. Tata McGraw-Hill Publishing Company Limited: New Delhi, India, 2001.

66. Adugna, A. Alternate approaches in deploying genes for diseases resistance in crop plants. Asian J. Plant Sci. 2004, 3, 618-623.

67. Kaga, A.; Ishii, T.; Tsukimoto, K.; Tokoro, E.; Kamijima, O. Comparative molecular mapping in Ceratotropis species using an inter-specific cross between $V$. umbellata and $V$. angularis. Theor. Appl. Genet. 2000, 100, 207-213.

68. Byrne, O.M.; Hardie, D.C.; Khan, T.N.; Speijers, J.; Yan, G. Genetic analysis of pod and seed resistance to pea weevil (B. pisorum) in a Pisum sativum $\times$ P. fulvum interspecific cross. Aust. J. Agic. Res. 2008, 59, 854-862.

69. Kogan, M. Plant Resistance in Pest Management. In Introduction to Insect Pest Management, 2nd ed.; John Willey \& Sons: New York, NY, USA, 1982; pp. 93-134.

(C) 2011 by the authors; licensee MDPI, Basel, Switzerland. This article is an open access article distributed under the terms and conditions of the Creative Commons Attribution license (http://creativecommons.org/licenses/by/3.0/). 